
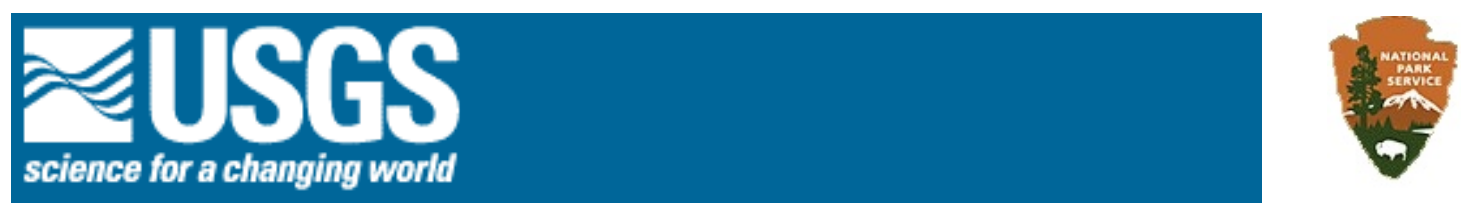

\title{
Coastal Vulnerability Assessment of Padre Island National Seashore (PAIS) to Sea-Level Rise
}

\author{
Elizabeth A. Pendleton, E. Robert Thieler, S. Jeffress Williams, and \\ Rebecca L. Beavers
}

U.S. Geological Survey Open-File Report 2004-1090, Electronic Book 2004

\begin{abstract}
A coastal vulnerability index $(\mathrm{CVI})$ was used to map the relative vulnerability of the coast to future sea-level rise within Padre Island National Seashore in Texas. The CVI ranks the following in terms of their physical contribution to sea-level rise-related coastal change: geomorphology, regional coastal slope, rate of relative sea-level rise, shoreline change rates, mean tidal range and mean significant wave height. The rankings for each variable were combined and an index value calculated for 1-minute grid cells covering the park. The CVI highlights those regions where the physical effects of sea-level rise might be the greatest. This approach combines the coastal system's susceptibility to change with its natural ability to adapt to changing environmental conditions, yielding a quantitative, although relative, measure of the park's natural vulnerability to the effects of sea-level rise. The CVI provides an objective technique for evaluation and long-term planning by scientists and park managers. Padre Island National Seashore consists of stable to washover dominated portions of barrier beach backed by wetland, marsh, tidal flat, or grassland. The areas within Padre that are likely to be most vulnerable to sea-
\end{abstract}


level rise are those with the highest occurrence of overwash and the highest rates of shoreline change.

\section{INTRODUCTION}

The National Park Service (NPS) is responsible for managing nearly $12,000 \mathrm{~km}(7,500$ miles) of shoreline along oceans and lakes. In 2001, the U.S. Geological Survey (USGS), in partnership with the NPS Geologic Resources Division, began conducting hazard assessments of future sea-level change by creating maps to assist NPS in managing its valuable coastal resources. This report presents the results of a vulnerability assessment for Padre Island National Seashore (PAIS), highlighting areas that are likely to be most affected by future sea-level rise.

Global sea level has risen approximately 18 centimeters (7.1 inches) in the past century (Douglas, 1997). Climate models predict an additional rise of $48 \mathrm{~cm}$ (18.9 in.) by 2100 (IPCC, 2002), which is more than double the rate of rise for the 20th century. Potential coastal impacts of sea-level rise include shoreline erosion, saltwater intrusion into groundwater aquifers, inundation of wetlands and estuaries, and threats to cultural and historic resources as well as infrastructure. Predicted accelerated global sea-level rise has generated a need in coastal geology to determine the response of a coastline to sea-level rise. However, an accurate and quantitative approach to predicting coastal change is difficult to establish. Even the kinds of data necessary to make shoreline response predictions are the subject of scientific debate. A number of predictive approaches have been proposed (National Research Council, 1990), including: 1) 
extrapolation of historical data (e.g., coastal erosion rates), 2) static inundation modeling, 3) application of a simple geometric model (e.g., the Bruun Rule), 4) application of a sediment dynamics/budget model, or 5) Monte Carlo (probabilistic) simulation based on parameterized physical forcing variables. However, each of these approaches has inadequacies or can be invalid for certain applications (National Research Council, 1990). Additionally, shoreline response to sea-level change is further complicated by human modification of the natural coast such as beach nourishment projects, and engineered structures such as seawalls, revetments, groins, and jetties. Understanding how a natural or modified coast will respond to sea-level change is essential to preserving vulnerable coastal resources.

The primary challenge in predicting shoreline response to sea-level rise is quantifying the important variables that contribute to coastal evolution in a given area. In order to address the multi-faceted task of predicting sea-level rise impact, the USGS has implemented a methodology to identify areas that may be most vulnerable to future sealevel rise (see Hammar-Klose and Thieler, 2001). This technique uses different ranges of vulnerability (low to very high) to describe a coast's susceptibility to physical change as sea level rises. The vulnerability determined here focuses on six variables which strongly influence coastal evolution:
1) Geomorphology
2) Historical shoreline change rate
3) Regional coastal slope 
4) Relative sea-level change

5) Mean significant wave height

6) Mean tidal range

These variables can be divided into two groups: 1) geologic variables and 2) physical process variables. The geologic variables are geomorphology, historic shoreline change rate, and coastal slope; they account for a shoreline's relative resistance to erosion, long-term erosion/accretion trend, and its susceptibility to flooding, respectively. The physical process variables include significant wave height, tidal range, and sea-level change, all of which contribute to the inundation hazards of a particular section of coastline over time scales from hours to centuries. A relatively simple vulnerability ranking system (Table 1) allows the six variables to be incorporated into an equation that produces a coastal vulnerability index $(\mathrm{CVI})$. The $\mathrm{CVI}$ can be used by scientists and park managers to evaluate the likelihood that physical change may occur along a shoreline as sea level continues to rise. Additionally, NPS staff will be able to incorporate information provided by this vulnerability assessment technique into general management plans.

\section{DATA RANKING}

Table 1 shows the six variables described in the Introduction, which include both quantitative and qualitative information. Actual variable values are assigned a vulnerability ranking based on value ranges, whereas the non-numerical geomorphology variable is ranked qualitatively according to the relative resistance of a given landform to 
erosion. Shorelines with erosion/accretion rates between -1.0 and $+1.0 \mathrm{~m} / \mathrm{yr}$ are ranked as moderate. Increasingly higher erosion or accretion rates are ranked as correspondingly higher or lower vulnerability. Regional coastal slopes range from very high vulnerability, $<0.3$ percent, to very low vulnerability at values $>1.2$ percent. The rate of relative sea-level change is ranked using the modern rate of eustatic rise $(1.8 \mathrm{~mm} / \mathrm{yr})$ as very low vulnerability. Since this is a global or "background" rate common to all shorelines, the sea-level rise ranking reflects primarily local to regional isostatic or tectonic adjustment. Mean wave height rankings range from very low $(<0.55 \mathrm{~m})$ to very high $(>1.25 \mathrm{~m})$. Tidal range is ranked such that microtidal $(<1 \mathrm{~m})$ coasts are very high vulnerability and macrotidal (>6 m) coasts are very low vulnerability.

\section{PADRE ISLAND NATIONAL SEASHORE}

Padre Island lies along the Gulf Coast of Texas and stretches 180 km (113 miles), which makes it the longest barrier island in the U.S. (Figure 1). A manmade channel divides Padre Island at Port Mansfield; otherwise the island would stretch uninterrupted from Corpus Christi to near Mexico. Mustang Island to the north is now connected to Padre Island due to the dredging of a ship channel at Aransas Pass (1880's), which resulted in the closure of Corpus Christi Pass. At its southern extent Padre Island is separated from Brazos Island by Brazos Santiago Pass. Padre Island is largely undeveloped because nearly 110 km (70 miles) of Padre Island (north of Port Mansfield channel) was established as a National Seashore in 1962 to preserve this pristine part of the Texas coast. 
Padre Island National Seashore can be broken up into three distinct morphological environments. Northern Padre Island can be characterized as a gently sloping sand beach with moderate sized dunes. In the central part of the island the beaches are steeper and consist mostly of shell, and the foredunes are high and mostly continuous. Here strong winds pile sand into dunes as high as 15 meters (50 feet). The south end of Padre Island National Seashore is a sand and shell mix beach that generally lacks a dune ridge and overwashes frequently. This is due to higher rates of erosion and less vegetation to hold sand in place (Weise and White, 1980).

Storm impacts on coastal evolution along the south coast of Texas are too numerous to detail here, but a comprehensive overview of storms and tracks along the coast of Texas since the 16 th century is hosted by the National Weather Service at http://www.srh.noaa.gov/lch/research/txhur.htm. This site emphasizes the impacts of Hurricane Bret (1999), which made landfall in Kenedy County and was responsible for between 12 to 20 overwashes within the National Seashore.

\section{METHODOLOGY}

In order to develop a database for a park-wide assessment of coastal vulnerability, data for each of the six variables mentioned above were gathered from state and federal agencies (Table 2). The database is based on that used by Thieler and Hammar-Klose (2000b) and loosely follows an earlier database developed by Gornitz and White (1992). A comparable assessment of the sensitivity of the Canadian coast to sea-level rise is presented by Shaw and others (1998). 
The database was constructed using a 1:70,000-scale shoreline for Padre Island that was produced from the medium resolution digital vector U.S. shoreline provided by the Strategic Environmental Assessments Division of NOAA's Office of Ocean Resources Conservation and Assessment (http://spo.nos.noaa.gov/projects/shoreline/shoreline.htm). Data for each of the six variables (geomorphology, shoreline change, coastal slope, relative sea-level rise, significant wave height, and tidal range) were added to the shoreline attribute table using a 1-minute (approximately $1.5 \mathrm{~km}$ ) grid (Figure 2). Next the data were assigned a relative vulnerability value from 1-5 (1 is very low vulnerability, 5 is very high vulnerability) based on the potential magnitude of its contribution to physical changes on the coast as sea level rises (Table 1).

\section{GEOLOGIC VARIABLES}

The geomorphology variable expresses the relative erodibility of different landform types (Table 1). These data were derived from 1-meter resolution digital orthophotos of Padre Island (Table 1). In addition, field visits were made within the park to ground-truth the geomorphologic classification. Another useful guidebook produced by the Bureau of Economic Geology was used for geomorphologic classification and background information (Weise and White, 1980). The geomorphology of Padre Island was classified such that the northern and southern portions of the seashore are very high vulnerability, and the central portion of Padre was classified as high vulnerability. The northern part of Padre has relatively stable continuous dunes but they are lower in height than the dunes in central Padre (Figure $3 \mathrm{~A}-\mathrm{C}$ and Figure $4 \mathrm{~A}-\mathrm{C}$ ). The southern portion of Padre Island consist of discontinous dune ridges with numerous washovers (Figure $5 \mathrm{~A}-\mathrm{C}$ ). 
Shoreline erosion and Accretion rates for Padre Island were calculated from existing shoreline data provided by the USGS National Assessment of Coastal Change project (Table 2). Shoreline rates of change ( $\mathrm{m} / \mathrm{yr}$ ) were calculated at $200 \mathrm{~m}$ intervals (transects) along the coast using Digital Shoreline Analysis System (DSAS) software (http://woodshole.er.usgs.gov/project-pages/dsas/) to derive the rate of shoreline change over time. The rates for each transect within a 1-minute grid cell were averaged to determine the shoreline change value used here, with positive numbers indication accretion and negative numbers indicating erosion. Shoreline change rates on Padre Island range from $2 \mathrm{~m} / \mathrm{yr}$ of accretion (low vulnerability) to greater than $2 \mathrm{~m} / \mathrm{yr}$ of erosion (very high vulnerability) (Figure 6 A-C). A $14 \mathrm{~km}$ gap in shoreline data existed within southern Kenedy County (Figure 7). We chose to extrapolate a rate, which was in agreement with data from another shoreline change estimate for this area (Morton and Pieper, 1977).

The determination of regional coastal slope identifies the relative vulnerability of inundation and the potential rapidity of shoreline retreat because low-sloping coastal regions should retreat faster than steeper regions (Pilkey and Davis, 1987). The regional slope of the coastal zone was calculated from a grid of topographic and bathymetric elevations extending landward and seaward of the shoreline. Elevation data were obtained from the National Geophysical Data Center (NGDC) as gridded topographic and bathymetric elevations at 0.1 meter vertical resolution for 3 arc-second $(\sim 90 \mathrm{~m})$ grid cells. Regional coastal slopes for Padre fall within the very high vulnerability category $(<$ $0.3 \%$ slope). 


\section{PHYSICAL PROCESS VARIABLES}

The relative sea-level change variable is derived from the increase or decrease in annual mean water elevation over time as measured at tide gauge stations along the coast. The rate of sea-level rise for Padre Island, TX is $3.44+/-0.56 \mathrm{~mm} / \mathrm{yr}$ based on 37 years of data (Zervas, 2001). This variable inherently includes both eustatic sea-level rise as well as regional sea-level rise due to isostatic and tectonic adjustments of the land surface. Relative sea-level change data are a historical record, and thus only portray the recent sea-level trend ( $<150$ years). Relative sea-level rise for Padre Island falls within very high vulnerability based on water elevation data at South Padre Island and Port Isabel.

Mean significant wave height is used here as a proxy for wave energy which drives the coastal sediment budget. Wave energy is directly related to the square of wave height:

\section{$E=1 / 8 \rho g H^{2}$}

where $E$ is energy density, $H$ is wave height, $\rho$ is water density and $g$ is acceleration due to gravity. Thus, the ability to mobilize and transport coastal sediments is a function of wave height squared. In this report, we use hindcast nearshore mean significant wave height data for the period 1976-95 obtained from the U.S. Army Corps of Engineers Wave Information Study (WIS) (see references in Hubertz and others, 1996). The model wave heights were compared to historical measured wave height data obtained from the NOAA National Data Buoy Center to ensure that model values were representative of the study area. For Padre Island, mean significant wave heights are between 0.8 and 1.0 $\mathrm{m}$, which represents low and moderate vulnerability, respectively. 
Tidal range is linked to both permanent and episodic inundation hazards. Tide range data were obtained from NOAA/NOS for a Gulf tide gauge at Corpus Christi and Brazos Santiago Pass. All of Padre Island is classified as very high vulnerability $(<1 \mathrm{~m})$ with respect to tidal range.

\section{COASTAL VULNERABILITY INDEX}

The coastal vulnerability index $(\mathrm{CVI})$ presented here is the same as that used in Thieler and Hammar-Klose (2000b) and is similar to that used in Gornitz and others (1994), as

well as to the sensitivity index employed by Shaw and others (1998). The CVI allows the six variables to be related in a quantifiable manner that expresses the relative vulnerability of the coast to physical changes due to future sea-level rise. This method yields numerical data that cannot be equated directly with particular physical effects. It does, however, highlight areas where the various effects of sea-level rise may be the greatest. Once each section of coastline is assigned a vulnerability value for each specific data variable, the coastal vulnerability index $(\mathrm{CVI})$ is calculated as the square root of the product of the ranked variables divided by the total number of variables;

$$
C V=\frac{\sqrt{a * b * c * d * e * f}}{6}
$$

where,$a=$ geomorphology, $\mathrm{b}=$ shoreline erosion/accretion rate, $\mathrm{c}=$ coastal slope, $\mathrm{d}$ $=$ relative sea-level rise rate, $e=$ mean significant wave height, and $f=$ mean tide range . The calculated CVI value is then divided into quartile ranges to highlight different 
vulnerabilities within the park. The CVI ranges (low - very high) reported here apply specifically to Padre Island National Seashore, and are not comparable to CVI ranges in other parks where the CVI has been employed (i. e. very high vulnerability means the same among parks; it's the numeric values that differ, such that a numeric value that equals very high vulnerability in one park may equal moderate vulnerability in another). To compare vulnerability between coastal parks, the national-scale studies should be used (Thieler and Hammar-Klose, 1999, 2000a, and 2000b). We feel this approach best describes and highlights the vulnerability specific to each park.

\section{RESULTS}

The calculated CVI values for Padre Island range from 7.75 to 16.14 . The mean CVI value is 11.27 ; the mode and the median are 10.21 . The standard deviation is 2.15 . The 25th, 50th, and 75th percentiles are $9.35,10.55$ and 12.75 , respectively.

Figure 8 shows a map of the coastal vulnerability index for Padre Island National Seashore. The CVI scores are divided into low, moderate, high, and very highvulnerability categories based on the quartile ranges and visual inspection of the data. CVI values below 9.35 are assigned to the low vulnerability category. Values from 9.4 to 10.55 are considered moderate vulnerability. High-vulnerability values lie between 10.6 and 12.75. CVI values above 12.75 are classified as very high vulnerability. Figure 9 shows a histogram of the percentage of Padre Island shoreline in each vulnerability category. Nearly $130 \mathrm{~km}$ (80 miles) of shoreline is evaluated along the national seashore. Of this total, seventeen percent of the mapped shoreline is classified as being at very high vulnerability due to future sea-level rise. Twenty-eight percent is classified 
as high vulnerability, twenty-nine percent as moderate vulnerability, and twenty-six percent as low vulnerability.

\section{DISCUSSION}

The data within the coastal vulnerability index $(\mathrm{CVI})$ show variability at different spatial scales (Figure 8). However, the ranked values for the physical process variables vary little over the extent of the shoreline. The value of the relative sea-level rise variable is constant at very high vulnerability for the entire study area. The significant wave height vulnerability is moderate to low, and the tidal range is very high vulnerability.

The geologic variables show the most variability and thus have the most influence on the CVI value (Figure 8). Geomorphology in the park includes high vulnerability barrier island shoreline with continuous dune ridges and very high vulnerability washoverdominated or low discontinuous dune areas. Vulnerability assessment based on historical shoreline change trends varies from low to very high (Figure 6 A-C). Regional coastal slope is in the very high vulnerability range for the extent of Padre Island.

The most influential variables in the CVI are geomorphology, shoreline change, and significant wave height; therefore they may be considered the dominant factors controlling how Padre Island will evolve as sea level rises. Geomorphology and significant wave height only vary between high and very high and moderate and low vulnerability, respectively; whereas the shoreline change variable ranges from low to very high. 


\section{CONCLUSIONS}

The coastal vulnerability index $(\mathrm{CVI})$ provides insight into the relative potential of coastal change due to future sea-level rise. The maps and data presented here can be viewed in at least two ways:

1) as indicators of where physical changes are most likely to occur as sea-level rises; and

2) as planning tools for the Padre Island National Seashore.

Padre Island National Seashore preserves a dynamic natural environment, which must be understood in order to be managed properly. The CVI is one way that a park can assess objectively the natural factors that contribute to the evolution of the coastal zone, and thus how the park may evolve in the future.

\section{REFERENCES}

Douglas, B.C., 1997, Global sea rise, a redetermination: Surveys in Geophysics, v. 18, p. $279-292$.

Gornitz, V. and White, T.W., 1992, A coastal hazards database for the U.S. West Coast: ORNL/CDIAC-81, NDP-043C, Oak Ridge National Laboratory, Oak Ridge, Tenn.

Gornitz, V.M., Daniels, R.C., White, T.W., and Birdwell, K.R., 1994, The development of a coastal vulnerability assessment database; vulnerability to sea-level rise in the U.S. southeast: Journal of Coastal Research, Special Issue No. 12, p. 327-338.

Hammar-Klose, E.S., and Thieler, E.R., 2001, Coastal vulnerability to sea-level rise, a preliminary database for the U.S. Atlantic, Pacific, and Gulf of Mexico coasts: U.S. Geological Survey, Digital Data Series DDS-68, 1 CD, Online. 
Hubertz, J.M., Thompson, E.F., and Wang, H.V., 1996, Wave information studies of U.S. coastlines; annotated bibliography on coastal and ocean data assimilation: WIS Report 36, U.S. Army Engineer Waterways Experiment Station, Vicksburg, 31 p.

IPCC, 2002, Climate change 2001, the scientific basis; contribution of working group I to the third assessment report of the Intergovernmental Panel on Climate Change: IPCC, Geneva, Switzerland, 563 p. (Also available on the Web at http://www.ipcc.ch)

Morton, R.A., and Pieper, M.J., 1977, Shoreline changes on central Padre Island (Yarborough Pass to Mansfield Channel): The University of Texas at Austin, Bureau of Economic Geology Geological Circular 77-2, 35 p.

National Research Council, 1990, Managing Coastal Erosion, Washington: National Academy Press, 163 p.

Pilkey, O.H., and Davis, T.W., 1987, An analysis of coastal recession models, North Carolina coast, in Nummedal, D. , Pilkey, O.H., and Howard, J.D. , eds., Sea-level Fluctuation and Coastal Evolution: SEPM (Society for Sedimentary Geology) Special Publications No. 41, Tulsa, Okla., p. 59-68.

Shaw, J., Taylor, R.B., Forbes, D.L., Ruz, M.H., and Solomon, S., 1998, Sensitivity of the Canadian coast to sea-level rise: Geological Survey of Canada Bulletin 505, 114 p.

Thieler, E.R., and Hammar-Klose, E.S., 2000a, National Assessment of Coastal Vulnerability to Sea-Level Rise, U.S. Pacific Coast: U.S. Geological Survey Open-File Report 00-178, 1 sheet. Online

Thieler, E.R., and Hammar-Klose, E.S., 2000b, National assessment of coastal vulnerability to sea-level rise, U.S. Gulf of Mexico Coast: U.S. Geological Survey, OpenFile Report 00-179, 1 sheet, $\underline{\text { Online. }}$

Thieler, E.R., and Hammar-Klose, E.S., 1999, National Assessment of Coastal vulnerability to Sea-Level Rise, U.S. Atlantic Coast: U.S. Geological Survey Open-File Report 99-593, 1 sheet. Online

Weise, B.R. and White, W.A., 1980, Padre Island National Seashore: A guide to the geology, natural environments and history of a Texas Barrier Island: The University of Texas at Austin, Bureau of Economic Geology Guidebook 17, 94 p.

White, W.A., Morton, R.A., Kerr, R.S., Kuenzi, W.D., and Brogden, W.B., 1979, Land and water resources, historical changes, and dune criticality, Mustand and North Padre Islands, Texas: The University of Texas at Austin, Bureau of Economic Geology Reports and Investigations RI0092.

Zervas, C., 2001, Sea level variations of the United States 1854-1999: NOAA Technical Report NOS CO-OPS 36, 201 p. 


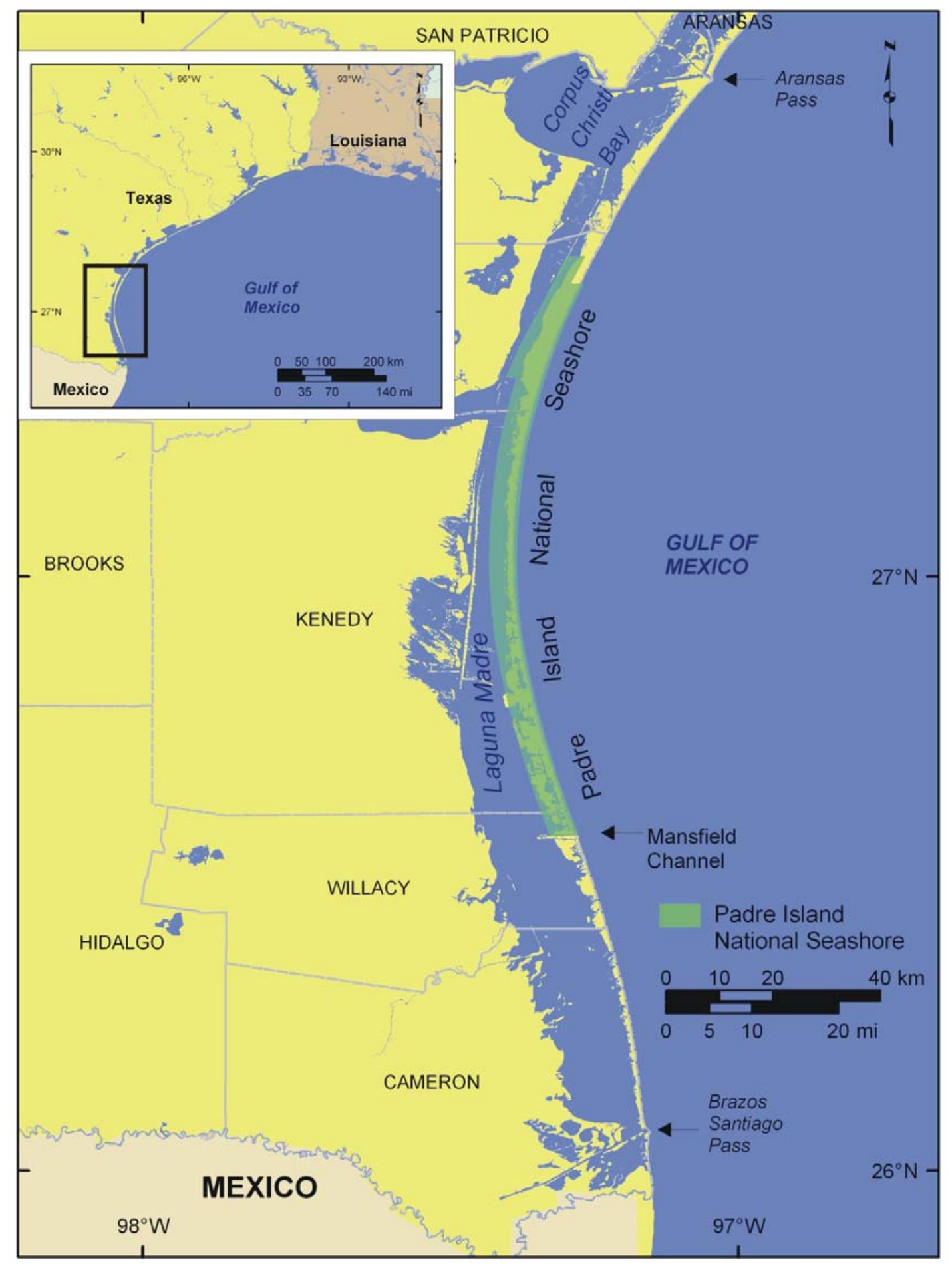

Figure 1: Location of Padre Island National Seashore along the Gulf of Mexico coast in Texas. 


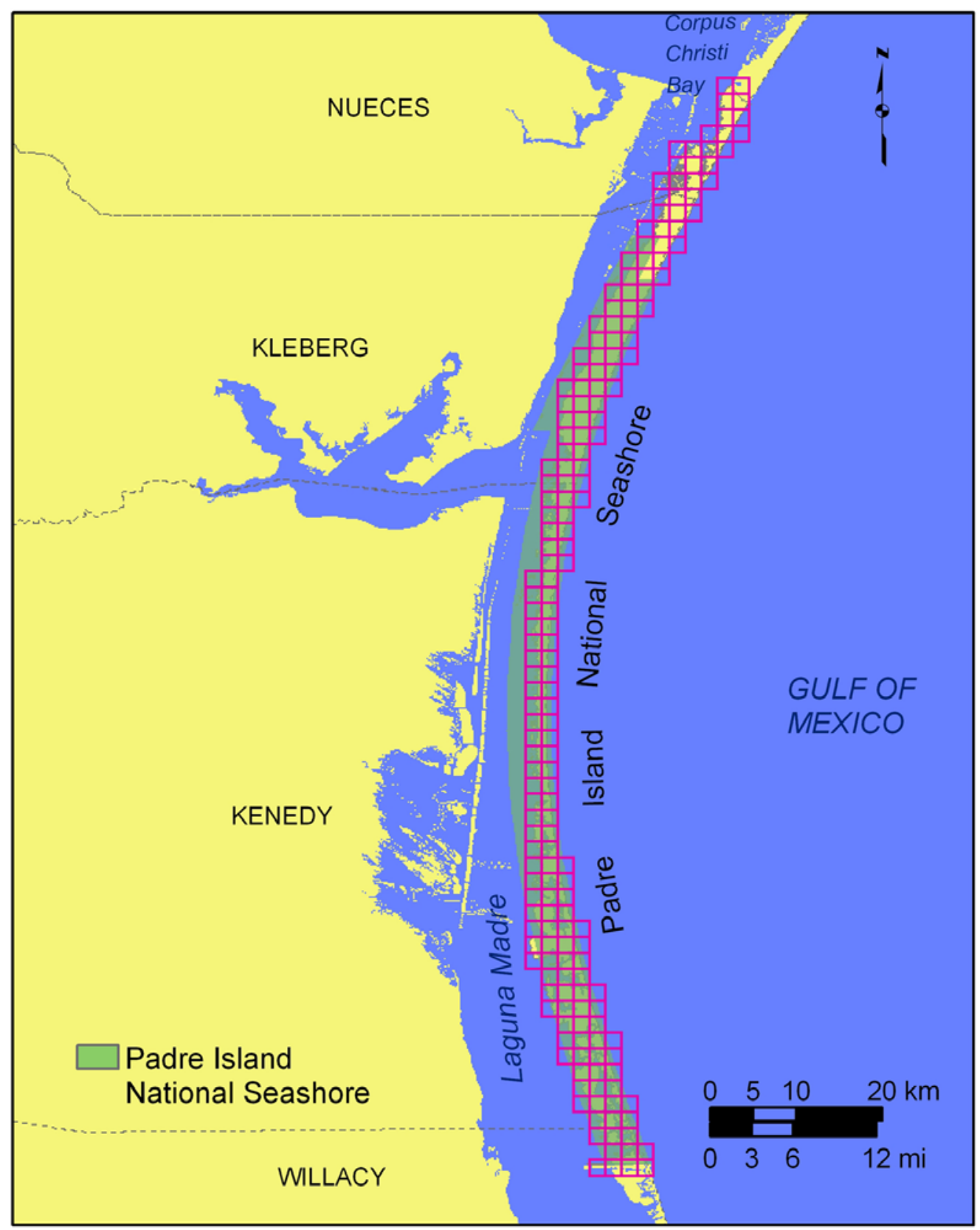

Figure 2: Shoreline grid for Padre Island National Seashore. 


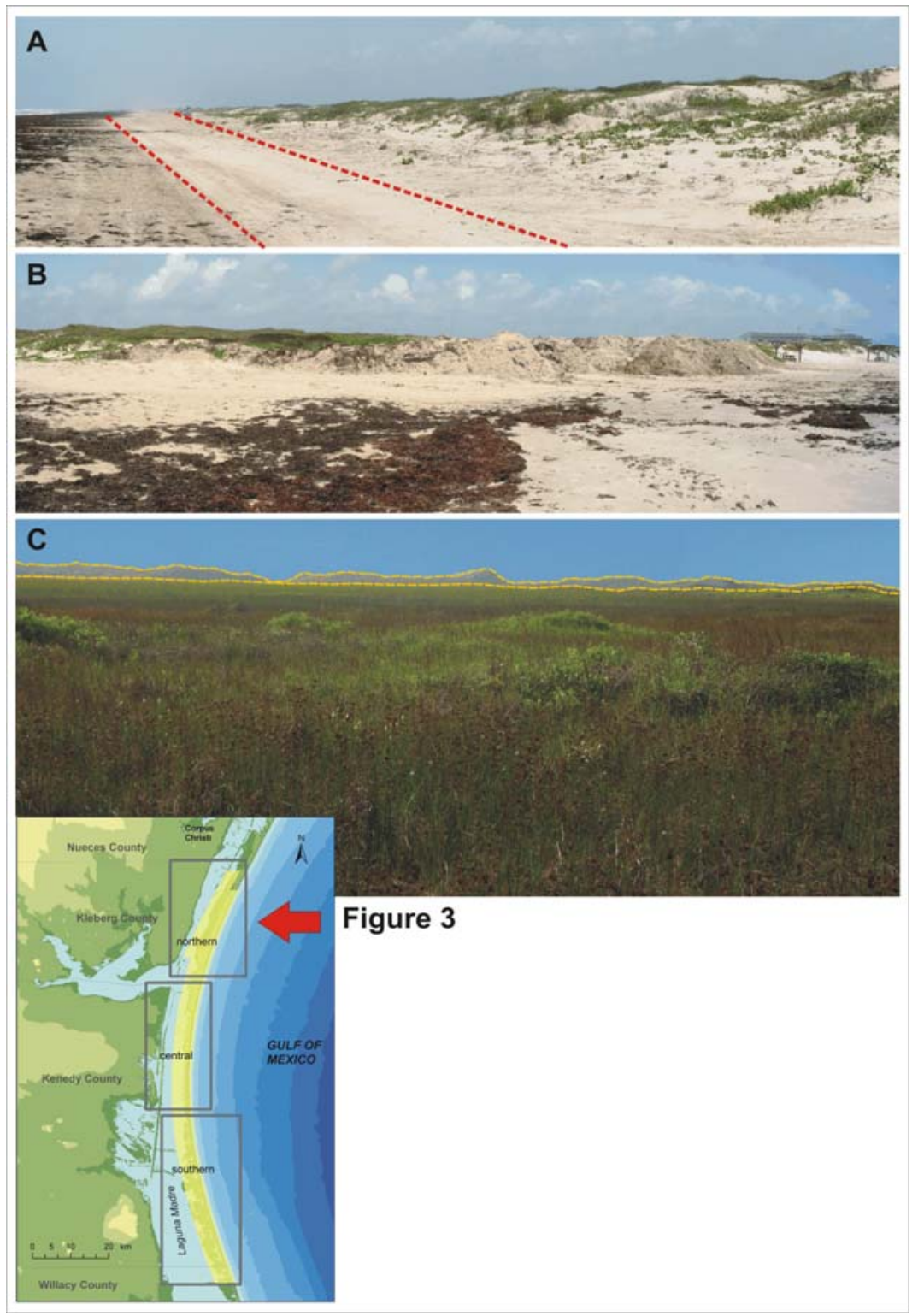

Figure 3: Northern Padre Island National Seashore (very high vulnerability with respect to geomorphology); A) Dunes along the Gulf side of Padre Island. This photo was taken north of the 4-wheel drive only area. High vehicle traffic here suppresses the formation and growth of coppice dunes (incipient dunes that generally form around vegetation at the base of the foredune ridge). The red-hatched lines show the vehicle path at the base of the foredune. B) Beach raking in front of the Malaquite Beach Visitor's Center provides a Sargassum free beach area for visitors, however these mounds of sand and seaweed are less stable than naturally vegetated dunes. C) Heavily vegetated backbarrier flat with small pond and marsh areas (not visible in photo). The Gulf-facing foredune ridge is outlined in gold, the dune ridge is not very high (compared to central PAIS) here but mostly continuous with just a few low areas. 


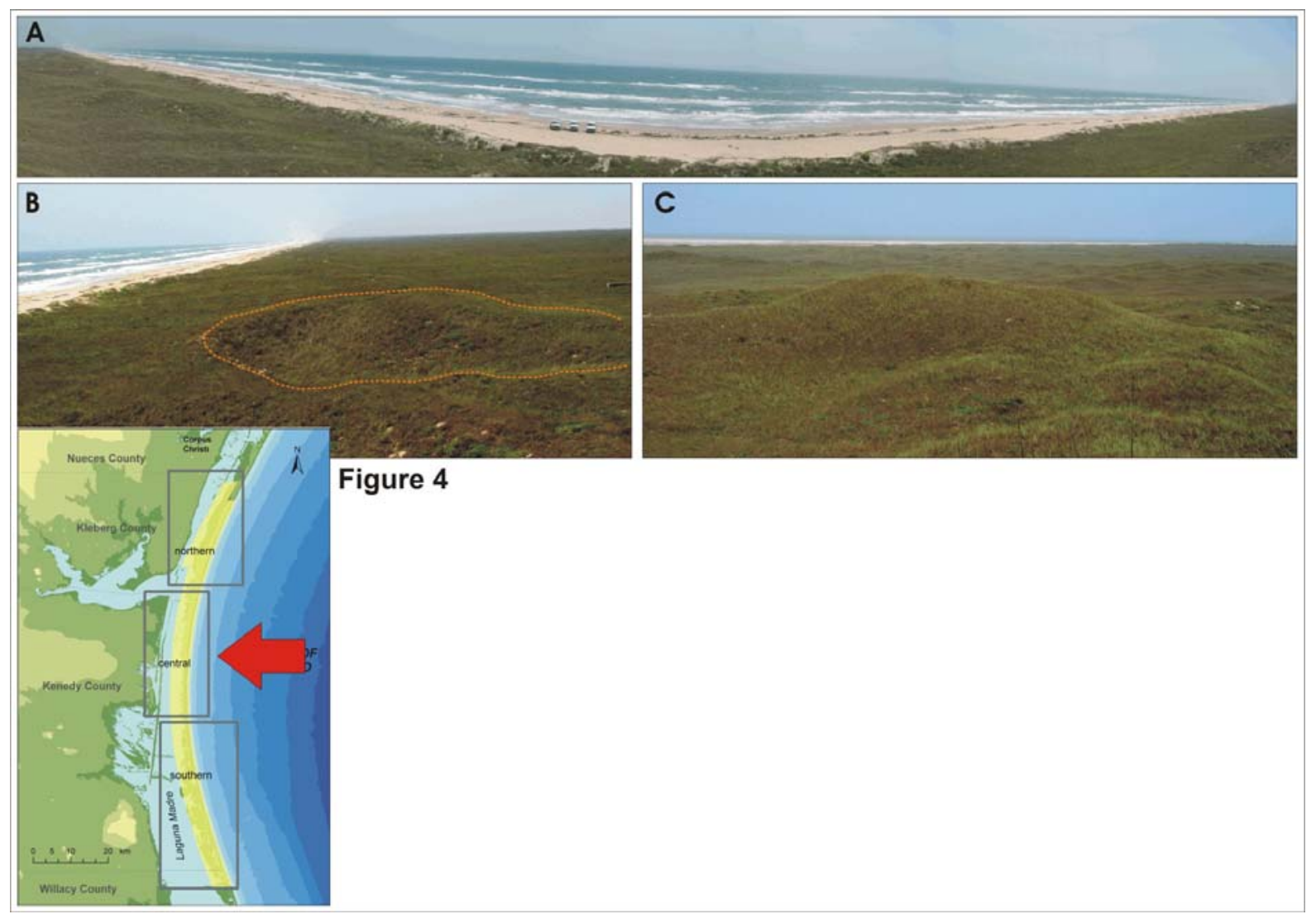

Figure 4: Central Padre Island National Seashore (high vulnerability with respect to geomorphology); A) View of Big Shell Beach from the highest point in the park, Green Hill (panoramically distorted). B) Stabilized blowout dune (outlined in yellow) near Green Hill. Central Padre island became more vegetated and many migrating dunes stabilized after the end of long droughts in the 1930's and 1950's (White and Others, 1979). Also the removal of cattle aided in dune stablization and vegetation. C) View of the hummocky well vegetated backbarrier looking towards Laguna Madre from Green Hill. 

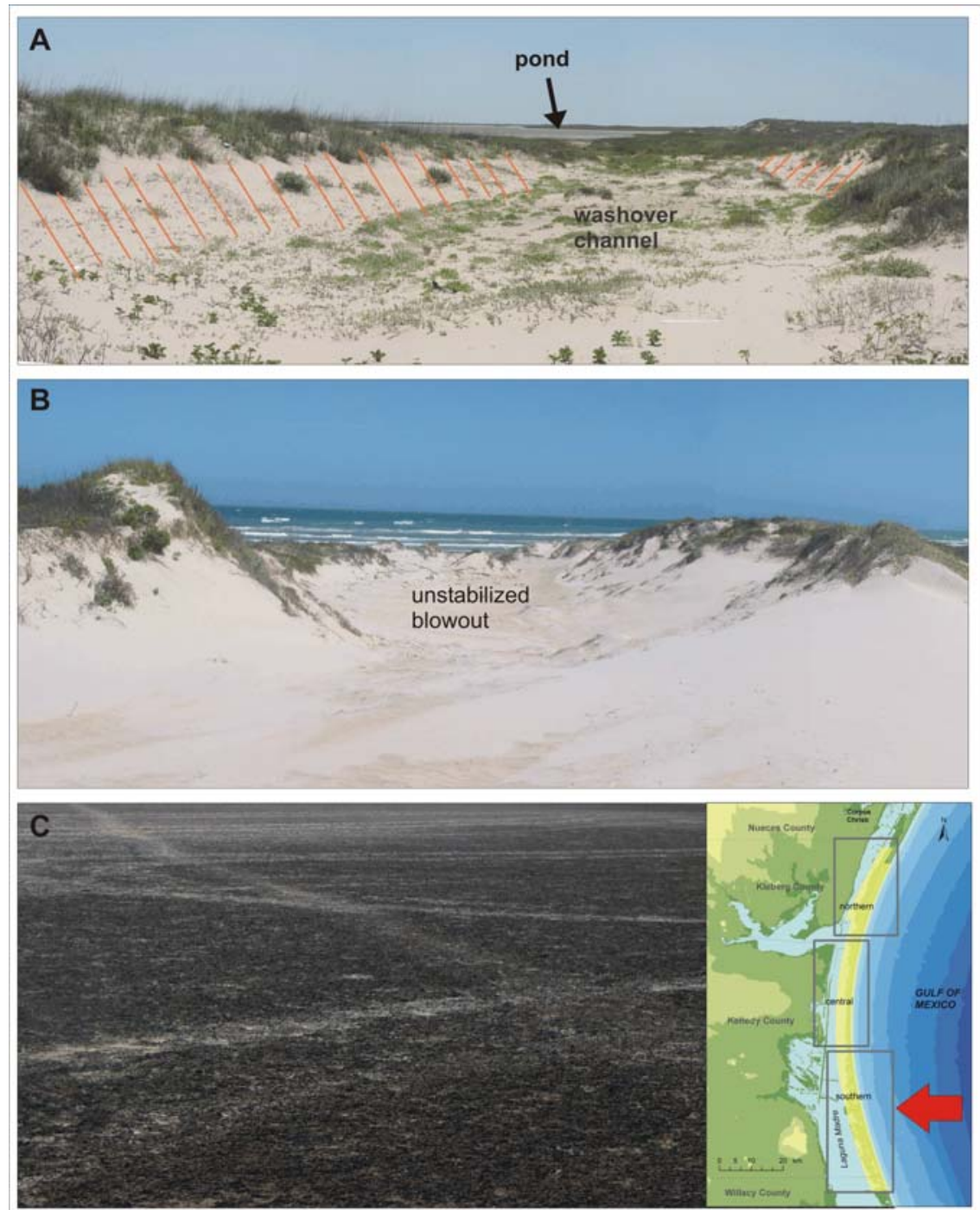

Figure 5

Figure 5: Southern Padre Island National Seashore (very high vulnerability with respect to geomorphology); A) Washover channel (from Hurricane Bret) backed by a pond. B) An unstabilized blowout dune. Unlike central PAIS, the southern part of the national seashore is less vegetated, so the dunes are more active and more vulnerable. C) An extensive wind tidal flat in the backbarrier near Laguna Madre that has developed an algal mat on the surface of the sand and mud. These environments form in all sections of PAIS, but seem to be most extensive and continuous to the south. 

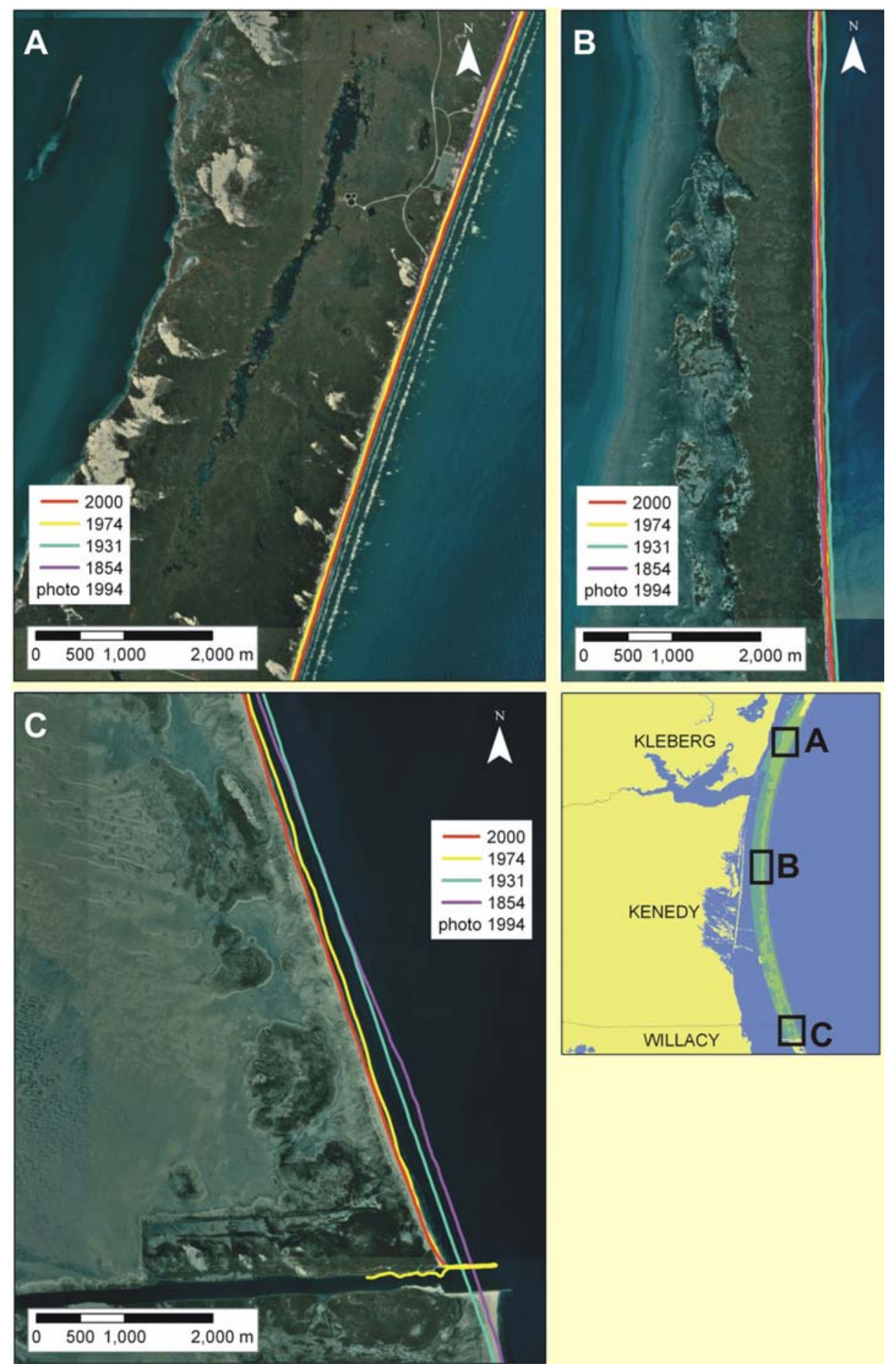

Figure 6: Historic Shoreline positions for A) northern PAIS - Malaquite Beach area, B) central PAIS - Big Shell Beach area, C) and southern PAIS - north of Port Mansfield Channel. 


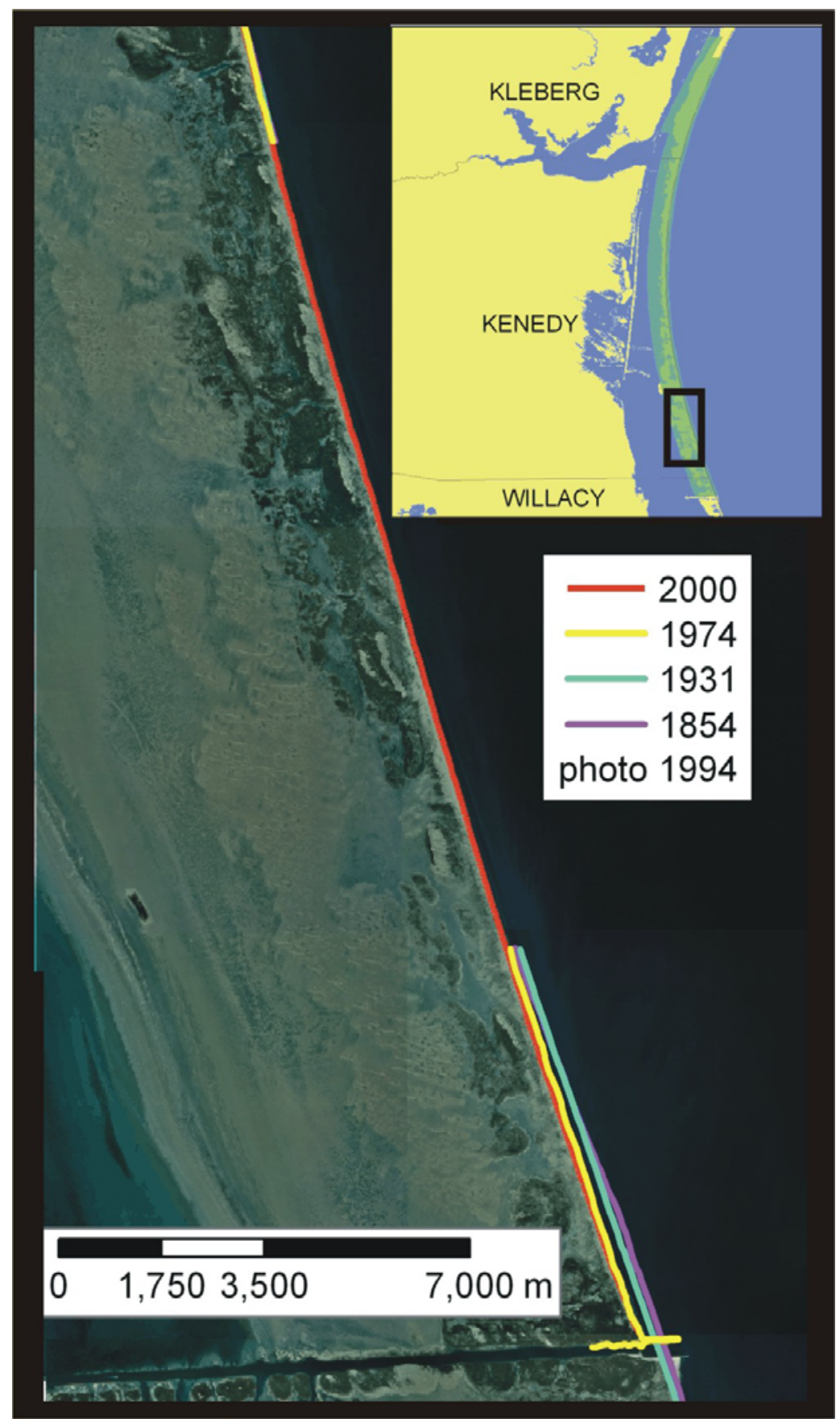

Figure 7: Location of the $14 \mathrm{~km}$ segment of shoreline in Kenedy County where there were not enough historic shorelines to calculate a rate of shoreline change. 


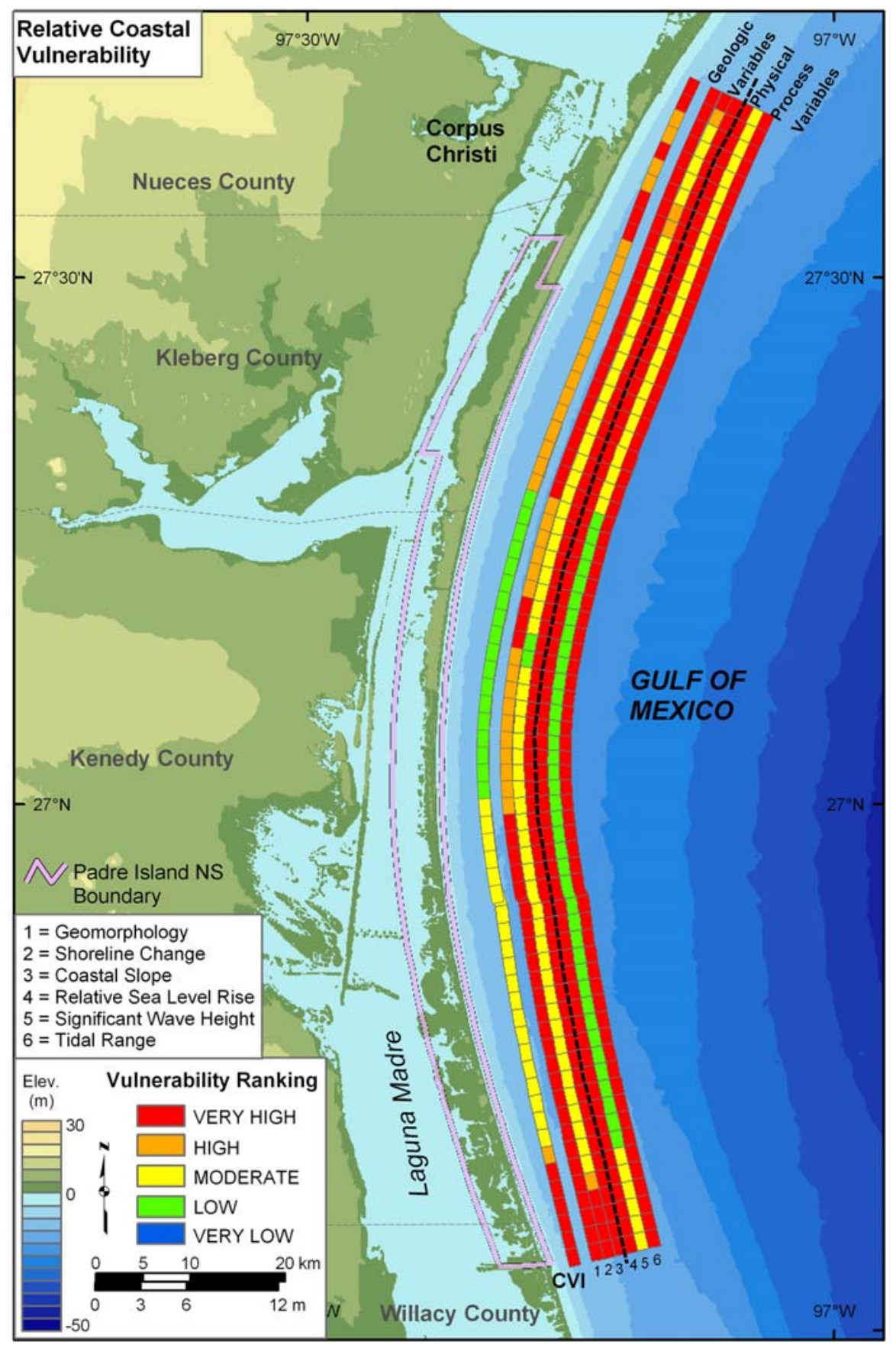

Figure 8: Relative Coastal Vulnerability for Padre Island National Seashore. The innermost color bar is the relative coastal vulnerability index (CVI). The remaining color bars are separated into the geologic variables (1-3) and physical process variables $(4-6)$. The very high vulnerability shoreline as defined by the CVI is located in washover or low dune areas where rates of shoreline erosion are highest. The low vulnerability shoreline is located in the central part of the island where dune ridges are high and continuous and shoreline accretion occurs. 


\section{Padre Island Vulnerability Categories}

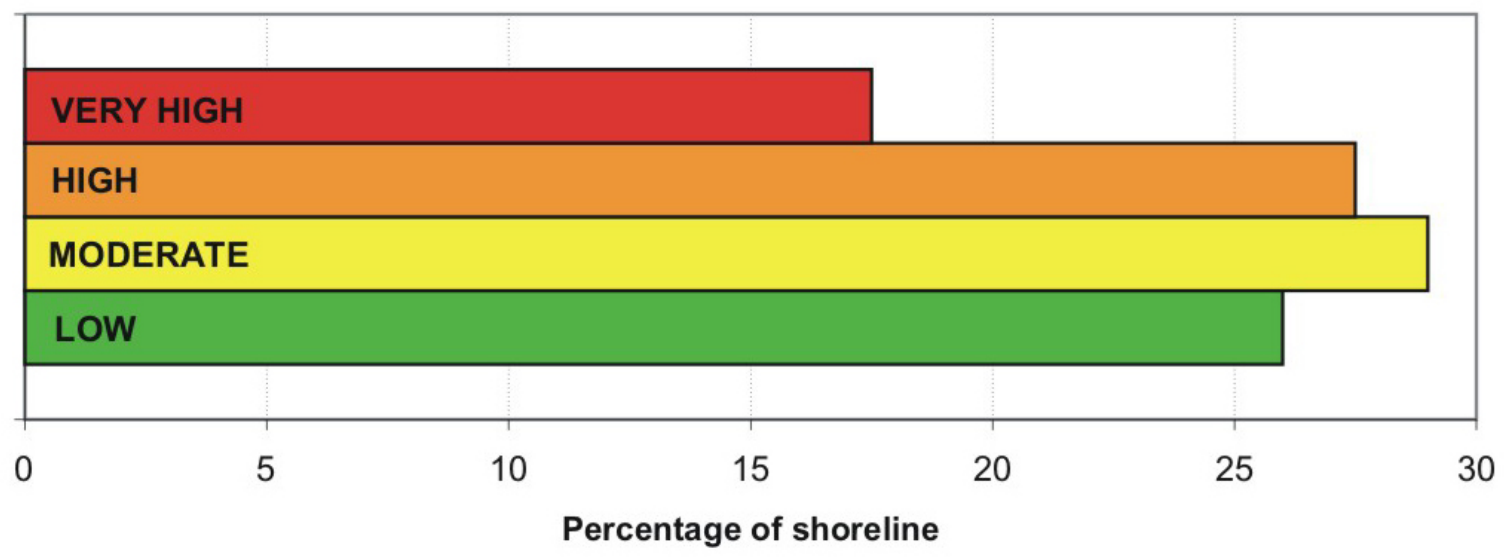

Figure 9: Percentage of PAIS shoreline in each CVI category. 
Table 1: Ranges for Vulnerability Ranking of Variables on the Gulf Coast.

\begin{tabular}{|c|c|c|c|c|c|}
\hline Variables & $\begin{array}{c}\text { Very Low } \\
1\end{array}$ & $\begin{array}{c}\text { Low } \\
2\end{array}$ & $\begin{array}{c}\text { Moderate } \\
3\end{array}$ & $\begin{array}{c}\text { High } \\
4\end{array}$ & $\begin{array}{c}\text { Very High } \\
5\end{array}$ \\
\hline GEOMORPHOLOGY & $\begin{array}{l}\text { Rocky cliffed } \\
\text { coasts, Fjords }\end{array}$ & $\begin{array}{l}\text { Medium } \\
\text { cliffs, } \\
\text { Indented } \\
\text { coasts }\end{array}$ & $\begin{array}{l}\text { Low cliffs, } \\
\text { Glacial drift, } \\
\text { Alluvial } \\
\text { plains }\end{array}$ & $\begin{array}{l}\text { Cobble } \\
\text { Beaches, } \\
\text { Estuary, } \\
\text { Lagoon }\end{array}$ & $\begin{array}{c}\text { Barrier beaches, } \\
\text { Sand beaches, Salt } \\
\text { marsh, Mud flats, } \\
\text { Deltas, Mangrove, } \\
\text { Coral reefs }\end{array}$ \\
\hline \begin{tabular}{|c|} 
SHORELINE \\
EROSION/ACCRETION \\
$(\mathrm{m} / \mathrm{yr})$
\end{tabular} & $>2.0$ & $1.0-2.0$ & $-1.0-1.0$ & $-2.0--1.0$ & $<-2.0$ \\
\hline COASTAL SLOPE (\%) & $>1.20$ & $1.20-0.90$ & $0.90-0.60$ & $0.60-0.30$ & $<0.30$ \\
\hline $\begin{array}{l}\text { RELATIVE SEA- } \\
\text { LEVEL CHANGE } \\
(\mathrm{mm} / \mathrm{yr})\end{array}$ & $<1.8$ & $1.8-2.5$ & $2.5-3.0$ & $3.0-3.4$ & $>3.4$ \\
\hline $\begin{array}{c}\text { MEAN WAVE HEIGHT } \\
(\mathrm{m})\end{array}$ & $<0.55$ & $0.55-0.85$ & $0.85-1.05$ & $1.05-1.25$ & $>1.25$ \\
\hline $\begin{array}{l}\text { MEAN TIDE RANGE } \\
(\mathrm{m})\end{array}$ & $>6.0$ & $4.0-6.0$ & $2.0-4.0$ & $1.0-2.0$ & $<1.0$ \\
\hline
\end{tabular}




\begin{tabular}{|c|c|c|}
\hline Variables & Source & URL \\
\hline GEOMORPHOLOGY & $\begin{array}{c}1994 \text { Orthophotos } \\
\text { (DOQs) from the Texas } \\
\text { Natural Resoures } \\
\text { Information System }\end{array}$ & http://www.tnris.state.tx.us/digital.htm \\
\hline $\begin{array}{c}\text { SHORELINE } \\
\text { EROSION/ACCRETION } \\
(\mathrm{m} / \mathrm{yr})\end{array}$ & $\begin{array}{c}\text { Texas coast shoreline } \\
\text { data (1854-2000) from } \\
\text { the US Geological } \\
\text { Survey }\end{array}$ & http://coastal.er.usgs.gov/national assessment/ \\
\hline COASTAL SLOPE (\%) & $\begin{array}{l}\text { NGDC Coastal Relief } \\
\text { Model Vol } 02\end{array}$ & http://www.ngdc.noaa.gov/mgg/coastal/coastal.html \\
\hline $\begin{array}{c}\text { RELATIVE SEA-LEVEL } \\
\text { CHANGE }(\mathrm{mm} / \mathrm{yr})\end{array}$ & $\begin{array}{c}\text { NOAA Technical Report } \\
\text { NOS CO-OPS } 36 \text { SEA } \\
\text { LEVEL VARIATIONS } \\
\text { OF THE UNITED } \\
\text { STATES 1854-1999 } \\
\text { (Zervas, 2001) }\end{array}$ & $\begin{array}{l}\text { http://www.co- } \\
\text { ops.nos.noaa.gov/publications/techrpt36doc.pdf }\end{array}$ \\
\hline $\begin{array}{l}\text { MEAN WAVE HEIGHT } \\
(\mathrm{m})\end{array}$ & $\begin{array}{c}\text { North Atlantic Region } \\
\text { WIS Data (Phase II) and } \\
\text { NOAA National Data } \\
\text { Buoy Center }\end{array}$ & $\begin{array}{l}\text { http://bigfoot.wes.army.mil/ } \\
\text { http://seaboard.ndbc.noaa.gov/ }\end{array}$ \\
\hline MEAN TIDE RANGE (m) & $\begin{array}{l}\text { NOAA/NOS CO-OPS } \\
\text { Historical Water Level } \\
\text { Station Index }\end{array}$ & http://www.co-ops.nos.noaa.gov/usmap.html \\
\hline
\end{tabular}

